OPEN ACCESS

Edited by:

Gang Rao,

Southwest Petroleum University,

China

Reviewed by:

Zhonghai Wu,

Chinese Academy of Geological

Sciences, China

Zhongtai He,

National Institute of Natural Hazards,

China

*Correspondence:

Wenjun Zheng

zhengwenjun@mail.sysu.edu.cn

Specialty section:

This article was submitted to Structural Geology and Tectonics,

a section of the journal

Frontiers in Earth Science

Received: 11 June 2021

Accepted: 14 July 2021

Published: 18 August 2021

Citation:

Liang S, Zheng W, Zhang D, Chen G,

Duan L, Yang J, Peng $H$ and Sun $X$ (2021) Paleoearthquakes Constrained by Stratigraphic Sequences of Different Drainages Since Late Pleistocene: A Case Study Along the Gulang Fault, NE

Tibetan Plateau.

Front. Earth Sci. 9:723751.

doi: 10.3389/feart.2021.723751

\section{Paleoearthquakes Constrained by Stratigraphic Sequences of Different Drainages Since Late Pleistocene: A Case Study Along the Gulang Fault, NE Tibetan Plateau}

\author{
Shumin Liang ${ }^{1,2,3}$, Wenjun Zheng ${ }^{1,2,3 *}$, Dongli Zhang ${ }^{1,2,3}$, Gan Chen ${ }^{1,2,3}$, Lei Duan ${ }^{1,2,3}$, \\ Jingjun Yang ${ }^{1,2,3}$, Hui Peng ${ }^{1,2,3}$ and Xin Sun ${ }^{1,2,3}$ \\ ${ }^{1}$ Guangdong Provincial Key Laboratory of Geodynamics and Geohazards, School of Earth Sciences and Engineering, Sun Yat- \\ sen University, Guangzhou, China, ${ }^{2}$ Southern Marine Science and Engineering Guangdong Laboratory (Zhuhai), Zhuhai, China, \\ ${ }^{3}$ State Key Laboratory for Earthquake Dynamics, Institute of Geology, China Earthquake Administration, Beijing, China
}

Paleoearthquake data obtained from fault trenching are essential for rebuilding the rupture history and understanding the rupture behavior of active faults. However, due to the lack of attention to stratigraphic sequences, the usual multiple trench constraining method may result in uncertainties of paleoearthquake sequences. In this study, we proposed an improved constraining method to generate stratigraphic sequences from multiple trenches of different drainages to obtain a paleoearthquake sequence of the Gulang fault. Singletrench stratigraphic sequences were built up by nineteen trenches excavated along the fault. Based on stratigraphic characteristics, we found the strata sedimented around the fault were derived from five drainages. The single-trench sequences were divided into five drainages to establish the composite sequence of multiple trenches through the correlation of stratigraphic units. Meanwhile, we used high-quality event indicators to pick out very likely earthquakes. Coupled with the dating samples, the events were used to determine the earthquake horizons in the composite sequence and to constrain the numbers and ages of events in each drainage. After combining the event sequences, six paleoearthquakes were determined along the Gulang fault since the late Pleistocene. Their occurrence timings are 13,700-10,400, 10,400-10,200, 8,560-7,295, 5,825-4,810, 4,285-3,200, and 2,615-2,240 a B.P. And their different rupture scenarios indicate that the fault might be composed of two rupture segments.

Keywords: drainage analysis, stratigraphic sequences, fault trenching, paleoearthquakes, rupture segmentation, Gulang fault

\section{INTRODUCTION}

The study of paleoearthquake is essential for understanding the long-term seismic behavior of faults. Based on the surface rupture remainders in geologic and geomorphic records, quantitative parameters of the prehistorical strong earthquakes, such as the occurrence timing and reoccurrence feature, can be obtained and further used to discuss the reoccurrence pattern, fault rupture segmentation, and seismic hazard assessment (e.g., Sieh, 1978; Schwartz and Coppersmith, 
1984; Weldon et al., 2002; Liu-Zeng et al., 2006; Scharer et al., 2007; Scharer et al., 2017; McCalpin, 2009; Ran et al., 2012a; Berryman et al., 2012). Trenching across faults provides key insights in studying paleoearthquake through stratigraphic record analysis, faulting interpretation, and age constraint from the dating samples (e.g., Sieh, 1978; Weldon et al., 2002; McCalpin, 2009; Burbank and Anderson, 2012). Many paleoearthquake studies along continental active faults have proved that it is common to miss some events in a single trench (e.g., Schwartz and Coppersmith, 1984; Zhang et al., 1988; Mao and Zhang, 1995; Zhang et al., 2005). However, the surface rupture of historical earthquakes indicates that the earthquake-derived evidence may not be obliterated but could be preserved along some fault sections (e.g., Lanzhou Institute of Seismology, 1995; Zheng et al., 2005; Ren et al., 2016). The earthquakes identified between different trenches are either repetitive or supplemental with each other, implying that multiple trenches excavated on different fault sections are possible to recover a complete sequence of recent paleoearthquakes.

Multiple trench constraining method is now widely used to refine the ages of paleoearthquakes. For example, an event logged in multiple trenches yielded slightly different age estimates, and the most likely age of the event would be the time window common to all these different ages (McCalpin, 1987; Khajavi et al., 2016; Guo et al., 2019). Only an upper or a lower age bound of a given event can be determined from a single trench because of the limitation of dating samples in many cases. The progressive constraining method is proposed to identify the same events by these upper and lower bounds and reduce the age interval by using multiple bounds (Mao and Zhang, 1995; Zhang et al., 2005). In recent years, the reliability of event interpretation has gained more attention. Similar geologic evidence caused by the nonearthquake processes increases the possibility to misestimate the number of paleoearthquakes, so a new system of evaluating event indicator was proposed to exclude the potential events without enough evidence (Scharer et al., 2007; Scharer et al., 2017; Yuan et al., 2018; Liu et al., 2021).

Little attention has been paid to stratigraphic characteristics; however, the stratigraphic interpretation and analysis in the trench is the prerequisite of event identification and sample dating. The best evidence for determining the number and the age of events is offered by the stratigraphy and deformation of unconsolidated sediments (e.g., Sieh, 1978; McCalpin, 2009). Ideally, more trenches are used, completer event sequences can be obtained, but it also means more complicated results of event identification and dating samples. Without the composite analysis of multiple trench stratigraphic sequences, nonearthquake events and dating outliers possibly lead to uncertainties in the identification of the stratigraphic horizon of paleoearthquake evidence, from which the quantity and age of events will be misestimated. The stratigraphic sequence is needed to be added to the multiple trench constraining method because it has the potential to test for event synchronicity and bring more precise event sequence out (Weldon et al., 2002; Bacon and Pezzopane, 2007; Goldfinger et al., 2008; Ferry et al., 2011).
In this study, the multiple trench constraining method was improved by combining the stratigraphic sequences of multiple trenches in different drainages to study the paleoearthquakes of the Gulang fault. According to stratigraphic characteristics, the trenches previously excavated on different fault sections have been divided into five drainages. Through the stratigraphic correlation between single-trench sequences, we built up the composite stratigraphic sequences of five drainages to which all potential events observed in trenches were matched. After the evaluation of event indicators, the earthquake horizons were picked out to constrain the event ages and conclude the paleoearthquake sequence of the fault. Furthermore, the practicability of this improved constraining method and the rupture behaviors of the Gulang fault were discussed.

\section{GEOLOGIC SETTING}

The Gulang fault (also named the Tianqiaogou-Huangyangchuan fault) is an important active fault in the eastern part of the northern Qilianshan fault zone in the northeastern Tibet (Wan, 1987; Dai et al., 1995; Gaudemer et al., 1995; Lanzhou Institute of Seismology, 1995; Lasserre et al., 2002). It splays eastward from the Qilian-Haiyuan fault zone and is located east of the Lenglongling fault (Figure 1B). Starting from Hongyaoxian and terminating in Jiapigou, the fault is $86 \mathrm{~km}$ long, striking near E-W (Figure 1C). It can be divided into two segments, the Tianqiaogou segment in the west and the Huangyangchuan segment in the east, by the Guanjiatai pull-apart basin (Dai et al., 1995; Dai et al., 1999; Lanzhou Institute of Seismology, 1995; Zheng et al., 2005). About $8 \mathrm{Ma}$, the Gulang fault turned into a strike-slip fault from a thrust fault (Gansu Bureau of Geology and Mineral Resources, 1989; Zhang et al., 2019). It is dominated by a left-lateral strike-slip with little thrust component. The Holocene left-lateral slip rate of the fault is estimated to be stable between 2 and $4.5 \mathrm{~mm} / \mathrm{a}$, while its vertical slip rate is mostly less than $0.5 \mathrm{~mm} / \mathrm{a}$ (Lanzhou Institute of Seismology, 1995; Zheng et al., 2005; Gao, 2018; Zhang et al., 2019). The M8.0 Gulang earthquake (Figure 1B) in 1927 is thought the largest historical earthquake along the Hexi Corridor (Gaudemer et al., 1995; Lanzhou Institute of Seismology, 1995; Hou et al., 2000), but whether the Gulang fault was ruptured by this event is still controversial (Hou, 1998; Zheng et al., 2005; Shi et al., 2019; Zhang et al., 2019).

There are distinct linear fault scarps and well-preserved faulted geomorphology along the Gulang fault, including the displaced gullies, fluvial terraces, alluvial fans, and mountain ridges (Lanzhou Institute of Seismology, 1995; Dai et al., 1999; Gao, 2018; Zhang et al., 2019). The fault has kept active in the late Quaternary. Trenches excavated across these offset geomorphic sites have been used to study the paleoearthquake history of the fault. Dai et al. (1995) had dug five trenches across the fault and found seven paleoearthquakes between 22,700 and 7,590 a B.P. with an average recurrence interval of about 3,350 a. And they suggested that the fault moved frequently from the late Pleistocene to the early Holocene but had become less active since the middle Holocene. However, by analyzing another six trenches, Zheng et al. (2005) reported seven paleoearthquakes and one historical earthquake along the fault in the Holocene. 


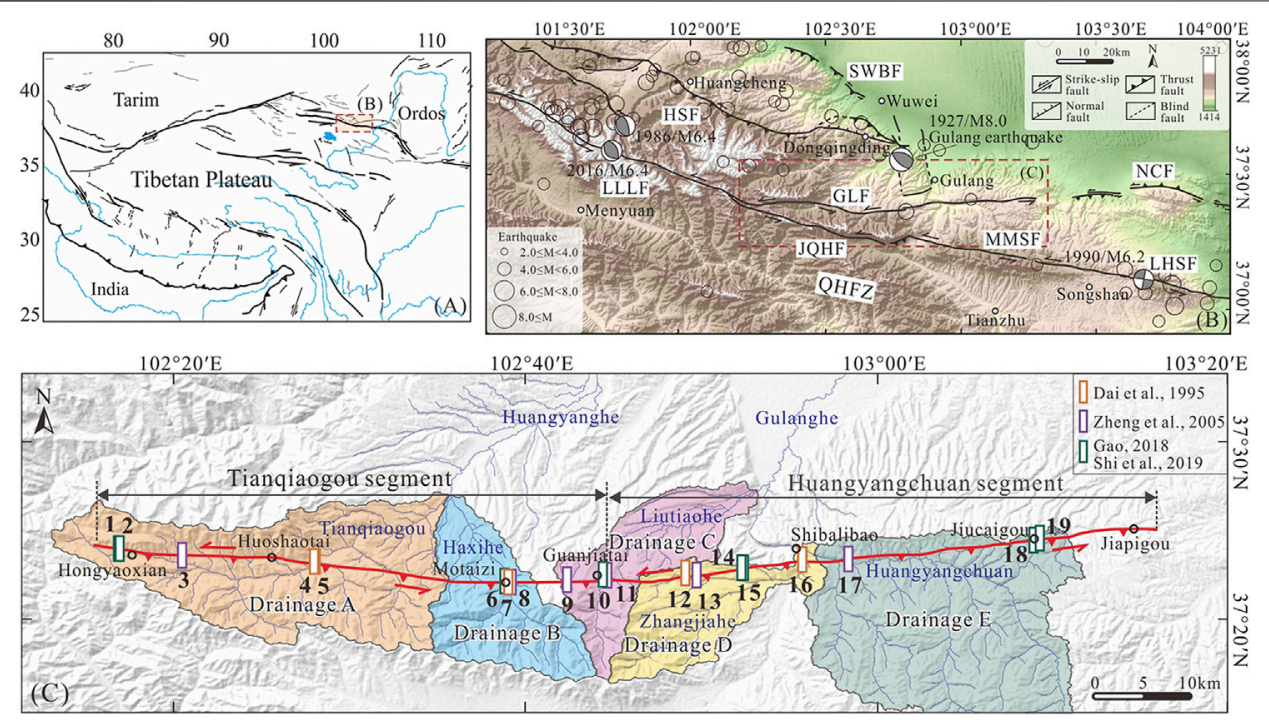

FIGURE 1 | Tectonic setting and distribution map of the Gulang fault. (A) Tectonic location of the study area. (B). Main active faults around the study area. The fault locations are modified from (Zheng et al., 2016) and (Guo et al., 2019). The seismic data (hollow dots) are from USGS. Focal mechanism solutions (gray beach balls) are from (Hou et al., 1999) and (He et al., 2020). Abbreviations: QHFZ = Qilian-Haiyuan fault zone; LLLF = Lenglongling fault; JQHF = Jinqianghe fault; MMSF = Maomaoshan fault; LHSF = Laohushan fault; HSF = Huangcheng-Shuangta fault; SWBF = South Wuwei Basin fault; GLF = Gulang fault; NCF = North Changlingshan fault. (C) Distribution map of the Gulang fault and five main drainages (Drainages A to E) along the fault. The fault locations are from (Shi et al., 2019). Rectangular boxes represent the trench locations.

TABLE 1 | Trenches: locations, geomorphic units, and sedimentary characteristics.

\begin{tabular}{|c|c|c|c|c|c|c|}
\hline Trench & No. & References & Segment & Drainages & Geomorphic unit & Sedimentary characteristics \\
\hline Hongyaoxian 1 & 1 & Gao (2018), Shi et al. (2019) & Tianqiaogou & Drainage A & T1 & - \\
\hline Hongyaoxian 2 & 2 & Gao (2018), Shi et al. (2019) & Tianqiaogou & Drainage A & $\mathrm{T} 1$ & - \\
\hline Yangjiawan & 3 & Zheng et al. (2005) & Tianqiaogou & Drainage A & Mountain ridge & Thin stratigraphic units \\
\hline Tianqiaogou 1 & 4 & Dai et al. (1995) & Tianqiaogou & Drainage A & $\mathrm{T} 1$ & - \\
\hline Tianqiaogou 2 & 5 & Dai et al. (1995) & Tianqiaogou & Drainage A & T1 & - \\
\hline Motaizi 1 & 6 & Gao (2018), Shi et al. (2019) & Tianqiaogou & Drainage B & $\mathrm{T} 2$ & Slope deposit \\
\hline Motaizi 2 & 7 & Dai et al. (1995) & Tianqiaogou & Drainage B & T3 & - \\
\hline Qianjingcun & 8 & Zheng et al. (2005) & Tianqiaogou & Drainage B & Mountain ridge & Thin stratigraphic units \\
\hline Dashigou & 9 & Zheng et al. (2005) & Tianqiaogou & Drainage C & Mountain ridge & Thin stratigraphic units \\
\hline Liutiaohe & 10 & Gao (2018), Shi et al. (2019) & Tianqiaogou & Drainage C & T2 & - \\
\hline Guanjiatai & 11 & Zheng et al. (2005) & Tianqiaogou & Drainage $\mathrm{C}$ & $\mathrm{T} 2$ & - \\
\hline Xiaoshigou 1 & 12 & Dai et al. (1995) & Huangyangchuan & Drainage D & $\mathrm{T} 2$ & Considerably different from surrounding trenches \\
\hline Xiaoshigou 2 & 13 & Zheng et al. (2005) & Huangyangchuan & Drainage D & $\mathrm{T} 2$ & - \\
\hline Kuangou 1 & 14 & Gao (2018), Shi et al. (2019) & Huangyangchuan & Drainage D & $\mathrm{T} 1$ & - \\
\hline Kuangou 2 & 15 & Gao (2018), Shi et al. (2019) & Huangyangchuan & Drainage D & $\mathrm{T} 1$ & Merely two dating samples with age inversion \\
\hline Gulanghe & 16 & Dai et al. (1995) & Huangyangchuan & Drainage $\mathrm{E}$ & $\mathrm{T} 2$ & Considerably different from surrounding trenches \\
\hline Youzhagou & 17 & Zheng et al. (2005) & Huangyangchuan & Drainage $\mathrm{E}$ & $\mathrm{T} 1$ & - \\
\hline Guodiwan & 18 & Gao (2018), Shi et al. (2019) & Huangyangchuan & Drainage E & T2 & - \\
\hline Jiucaigou & 19 & Gao (2018), Shi et al. (2019) & Huangyangchuan & Drainage $\mathrm{E}$ & $\mathrm{T} 1$ & Fine-grained sag pond filling materials \\
\hline
\end{tabular}

These eight events were characterized by quasi-periodic recurrence with an average interval of about 1,500 a. Besides, two trenches opened by Shi et al. (2019) showed at least five paleoearthquakes with their moment magnitudes estimated to be Mw7.3-7.4 occurring on the Gulang fault in the Holocene and their average recurrence interval is about 2,400 a. Several paleoearthquake investigations have been carried out, in which different geomorphic units, dating methods, and multiple trench constraining methods were applied. They finally led to inconsistent paleoearthquake sequences. Therefore, additional work is highly required to unravel the long-term paleoearthquake behavior of the fault.

Totally, nineteen trenches excavated by previous studies (Figure 1C and Table 1; Dai et al., 1995; Zheng et al., 2005; Gao, 2018; Shi et al., 2019) have been collected. They are uniformly distributed along the fault with the westernmost one located in Hongyaoxian and the easternmost one located in Jiucaigou. The majority of them are excavated on the displaced fluvial terraces $\left(\mathrm{T}_{1}-\mathrm{T}_{3}\right.$ from young to old), while three trenches are excavated on the dislocated mountain ridges. A new 


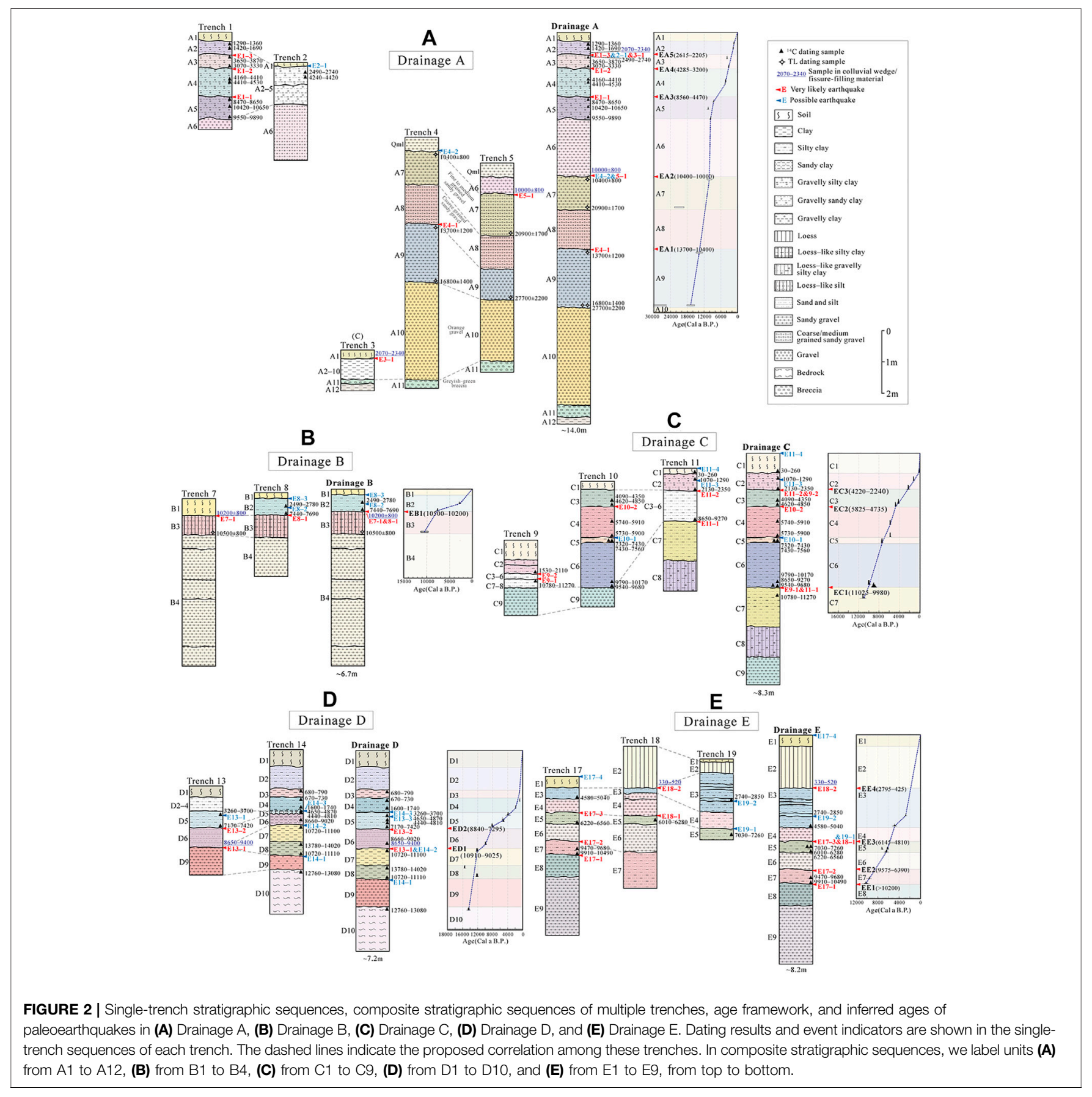

systematic analysis based on the stratigraphic sequences of these trenches would be presented to rebuild the paleoearthquake history of the Gulang fault.

\section{DATA AND METHODS}

\section{Stratigraphic Sequence Establishment}

The single-trench stratigraphic sequences (Figure 1C and Table 1) were established first (Figure 2). More materials are likely to deposit on the footwall in which a completer stratigraphic sequence should be preserved because the footwall is low-lying over a period of time after faulting. The top of the hanging wall has probably used to be eroded, yielding the sedimentary interruption and the destruction of earthquakederived evidence. The footwall of the Gulang fault is the north wall. In the trenches, the portions of the footwall with more nearhorizontal layers and dating samples would be a better alternative. The colluvial wedge and fissure-filling material are the local sedimentary product of faulting so they were not considered in the establishment of stratigraphic sequences. To expose the entire thickness of the stratigraphic unit, the thickness of the 
TABLE 2 | Recalibration of radiocarbon samples.

\begin{tabular}{|c|c|c|c|c|c|}
\hline Trench no & Sample & Sample type & Sample layer & Radiocarbon age (a B.P.) & Calendar age (Cal B.P.) $(2 \sigma)$ \\
\hline \multirow[t]{9}{*}{1} & HYXW20 & Organic sediment & Gravelly silty clay & $1,420 \pm 30$ & $1,290-1,360$ \\
\hline & HYXE22 & Charcoal & Gravelly silty clay & $1,670 \pm 30$ & 1,420-1,690 \\
\hline & HYXE2O & Organic sediment & Gravelly silty clay & $3,500 \pm 30$ & $3,650-3,870$ \\
\hline & HYXE23 & Charcoal & Gravelly silty clay & $2,990 \pm 30$ & 3,070-3,330 \\
\hline & HYXE04 & Charcoal & Gravelly silty clay & $3,870 \pm 30$ & $4,160-4,410$ \\
\hline & HYXW03 & Charcoal & Gravelly silty clay & $4,000 \pm 30$ & $4,410-4,530$ \\
\hline & HYXE03 & Charcoal & Gravelly silty clay & $7,810 \pm 30$ & 8,470-8,650 \\
\hline & HYXE05 & Charcoal & Gravelly silty clay & $9,330 \pm 30$ & $10,420-10,650$ \\
\hline & HYXE01 & Organic sediment & Gravelly silty clay & $8,720 \pm 30$ & $9,550-9,890$ \\
\hline \multirow[t]{4}{*}{2} & - & - & Gravelly silty clay & $2,510 \pm 30$ & $2,490-2,740$ \\
\hline & - & - & Gravelly silty clay & $3,900 \pm 30$ & $4,240-4,420$ \\
\hline & - & - & Colluvial wedge & $5,520 \pm 30$ & $6,280-6,400$ \\
\hline & - & - & Colluvial wedge & $7,860 \pm 40$ & $8,540-8,970$ \\
\hline 3 & LUG-02-129 & - & Silty clay & $2,213 \pm 50$ & $2070-2,340$ \\
\hline \multirow[t]{2}{*}{8} & LUG02-125 & - & Silty clay & $2,571 \pm 53$ & $2,490-2,780$ \\
\hline & LUG02-126 & - & Silty clay & $6,732 \pm 65$ & $7,440-7,690$ \\
\hline \multirow[t]{2}{*}{9} & LUG02-130C & Charcoal & Silty clay & $1865 \pm 121$ & 1,530-2,110 \\
\hline & LUG02-131 & - & Silty clay & $9,730 \pm 75$ & $10,780-11,270$ \\
\hline \multirow[t]{8}{*}{10} & W58 & - & Silty clay & $3,810 \pm 30$ & $4,090-4,350$ \\
\hline & E44 & - & Silty clay & $4,210 \pm 30$ & $4,620-4,850$ \\
\hline & E42 & - & Silty clay & $5,070 \pm 30$ & $5,740-5,910$ \\
\hline & E37 & - & Silty clay & $5,060 \pm 30$ & $5,730-5,900$ \\
\hline & E25 & - & Silty clay & $6,480 \pm 30$ & $7,320-7,430$ \\
\hline & E40 & - & Silty clay & $6,580 \pm 30$ & $7,430-7,560$ \\
\hline & E04 & - & Breccia & $8,870 \pm 30$ & $9,790-10,170$ \\
\hline & E05 & - & Breccia & $8,660 \pm 30$ & $9,540-9,680$ \\
\hline \multirow[t]{4}{*}{11} & LUG02-101 & - & Soil & $-47 \pm 47$ & 30-260 \\
\hline & LUG02-100 & - & Gravelly silty clay & $1,270 \pm 42$ & 1,070-1,290 \\
\hline & LUG02-99 & - & Gravelly silty clay & $2,262 \pm 54$ & $2,130-2,350$ \\
\hline & LUG02-98 & - & Silty clay & $8,072 \pm 79$ & $8,650-9,270$ \\
\hline \multirow[t]{3}{*}{13} & LUG02-104 & - & Silty clay & $3,258 \pm 86$ & $3,260-3,700$ \\
\hline & LUG02-102 & - & Silty clay & $6,371 \pm 68$ & $7,170-7,420$ \\
\hline & LUG02-103 & - & Silty clay & $8,110 \pm 100$ & $8,650-9,400$ \\
\hline \multirow[t]{10}{*}{14} & KG22 & Charcoal & Clay & $840 \pm 30$ & $680-790$ \\
\hline & KG23 & Charcoal & Silty clay & $770 \pm 30$ & 670-730 \\
\hline & KG26 & Charcoal & Silty clay & $1,790 \pm 30$ & $1,600-1740$ \\
\hline & KG25 & Charcoal & Loess & $4,250 \pm 30$ & $4,650-4,870$ \\
\hline & KG32 & Charcoal & Loess & $4,080 \pm 30$ & $4,440-4,810$ \\
\hline & KG24 & Organic sediment & Clay & $8,020 \pm 40$ & 8,660-9,020 \\
\hline & KG29 & Organic sediment & Sandy clay & $9,560 \pm 40$ & $10,720-11,100$ \\
\hline & KG36 & Charcoal & Clay & $11,980 \pm 40$ & $13,780-14,020$ \\
\hline & KG17 & Organic sediment & Clay & $9,570 \pm 40$ & $10,720-11,110$ \\
\hline & KG43 & Charcoal & Bedrock & $10,970 \pm 90$ & $12,760-13,080$ \\
\hline \multirow[t]{4}{*}{17} & LUG02-120 & - & Silty clay & $4,272 \pm 63$ & $4,580-5,040$ \\
\hline & LUG02-119 & - & Silty clay & $5,599 \pm 74$ & $6,220-6,560$ \\
\hline & LUG02-121 & - & Silty clay & $8,576 \pm 58$ & $9,470-9,680$ \\
\hline & LUG02-117 & - & Silty clay & $9,054 \pm 87$ & $9,910-10,490$ \\
\hline \multirow[t]{2}{*}{18} & GDW10 & - & Silty clay & $420 \pm 30$ & $330-520$ \\
\hline & GDW15 & - & Silty clay & $5,370 \pm 30$ & $6,010-6,280$ \\
\hline \multirow[t]{2}{*}{19} & - & - & Silty clay & $2,660 \pm 30$ & $2,740-2,850$ \\
\hline & - & - & Silty clay & $6,260 \pm 30$ & $7,030-7,260$ \\
\hline
\end{tabular}

Symbol - herein indicates that the name or type of the radiocarbon dating sample was not reported in references. 
stratigraphic unit was determined by the thickest portions that are not anomalous or obviously structurally controlled. Trenches 3,8 , and 9 were excavated on the dislocated mountain ridges (Table 1) on which the erosion rate is higher. Their stratigraphic units are much thinner than those of other trenches (Figure 2).

Furthermore, different radiocarbon calibration methods used in previous studies might make difference in age determination of the stratigraphic units; thus, we provided a consistent recalibration (Table 2) in the radiocarbon measurements on all radiocarbon dating sample by applying the OxCal 4.4 program and the IntCal 20 curve (Reimer et al., 2020). In Trench 2, there is an age inversion of dating samples in two older colluvial wedges, and the contact relation between two colluvial wedges and stratigraphic units in Trench 2 is unusual (Gao, 2018; Shi et al., 2019), so the dating samples within these two older wedges were not taken into account in the sequence establishment.

In different drainages, different sources of sediments and hydrodynamic conditions can result in different sediments and stratigraphic characteristics. Five main drainages can be found along the Gulang fault, involving the Tianqiaogou, Haxihe, Liutiaohe, Zhangjiahe, and Huangyangchuan, from west to east. Nineteen trenches were divided into these five drainages to integrate the single-trench stratigraphic sequences and establish the composite stratigraphic sequences of multiple trenches (Figure 1C). Glacier and frozen soil at high altitudes are the sediment supplies of the trenches along the Tianqiaogou in Drainage A. The sediments of trenches in Drainages B, C, and D are derived from snowmelt and fluvial erosion of the Haxihe, Liutiaohe, and Zhangjiahe, respectively. And the sediments of the trenches in Drainage E mainly come from the Quaternary unconsolidated sediments transported by the Huangyangchuan. The trenches in Drainage A contain more sand and gravel, while the component of clay increases and the loess unit appears in the trenches in Drainages B, C, and D (Figure 2). It might be the result of a stronger hydrodynamic condition in Drainage A but weaker ones in Drainages B, C, and $D$. In the trenches of Drainage $E$ (Figure 2E), a sandy gravel unit is commonly observed between two silty clay units, possibly revealing a variable hydrodynamic condition.

The correlation of stratigraphic units among multiple trenches is based on the marker stratigraphic unit, sedimentary characteristics (grain size and color), and dating samples of similar age. Various sedimentation rates and erosion rates in the trenches, combined with different judgments about lithology and stratification from the previous studies, produce a certain influence on our stratigraphic correlation. We tried to refine the sediment stratification and recover the unit thickness reasonably during the unit correlation as far as possible. When regarding Trenches $6,12,15$, and 16, their original limited description, age inversion of dating samples, and considerably different stratigraphic sequences from those of the surrounding trenches (Dai et al., 1995; Gao, 2018; Shi et al., 2019) excluded them from the composite stratigraphic sequence establishment.

In Drainage A (Figure 2A), the transition from gravelly silty clay to sandy gravel between units A5 and A6 is sharp at approximately $10 \mathrm{ka}$. Two maker units, unit A10 composed of orange gravel and unit A11 composed of greyish-green breccia, link Trench 5 with Trench 4 . And the sediment grain coarsening from unit A7 to unit A8 also matches, although there are different dating results between these two trenches. In Drainage $B$ (Figure 2B), unit B3 of loess-like silt or silty clay and unit B4 of sandy gravel can be thought of as two marker units. Unit C2 in Drainage $\mathrm{C}$ is mostly shown as gravelly silty clay and unit $\mathrm{C} 9$ is shown as gravel or sandy gravel (Figure 2C). Units C3 to C8 are mostly composed of silty clay and they are correlated among Trenches 9, 10, and 11 based on the dating samples of similar ages. For example, units C3 to C6 are silty clay formed between 10 and $2.3 \mathrm{ka}$. The components of sand and gravel increase in units D6 and D9 in Drainage D, respectively (Figure 2D). The correlation of units D2 to D5 is mainly constrained by the dating results. For example, unit D5 is silty clay or loess deposited between 7.5 and $3 \mathrm{ka}$. In Drainage E (Figure 2E), the interbed of silty clay unit and sandy gravel unit from unit E3 to unit E7 matches Trench 18 with Trench 17 well. Trench 19 is composed of the fine-grained filling materials in the sag pond because it was excavated in a sag pond east of the Jiucaigou village (Gao, 2018; Shi et al., 2019). The correlation of Trench 19 with the other two trenches is mainly determined by the dating results. Overall, the sediments were dominated by gravel before $10 \mathrm{ka}$ and the grain size has become finer since $10 \mathrm{ka}$ in these five drainages, indicating a dramatic change of climatic or hydrologic conditions (Shen et al., 2005; Sun and Colin, 2014).

\section{Event Indicator Analysis}

Without the influence of faulting, the stratigraphic unit in the trench should keep in its original and natural state, for example, shown as a horizontal layer with consistent or gradual varying thickness. The deformation and disruption of the stratigraphic unit will be regarded as a possible paleoearthquake indicator. Common event indicator includes a colluvial wedge, sag pond sediment, material-filled fissure, vertical offset of stratigraphic unit, upward termination of fault, angular unconformity, and growth strata (McCalpin, 2009; Ran et al., 2012a; Ran et al., 2012b). They are the critical evidence from which we pick up each interpreted event and which help us to distinguish observations from earthquake horizons. The highest-quality event indicators are the sedimentary characteristics which can only be caused by an earthquake, while there may be some other types of nonearthquake triggering mechanisms for the low-quality indicators. The event indicators of high quality can be used to identify very likely earthquakes (Scharer et al., 2007; Scharer et al., 2017; Liu-Zeng et al., 2015; Yuan et al., 2018). The quality of individual event indicators is the most important factor in paleoearthquake identification. To document the quality of event indicators observed in the trenches, all event indicators have been tabulated in Table 3. The trenches exhibit a wide variety of event indicators.

The colluvial wedge, sag pond sediment, and material-filled fissure herein are the high-quality indicators required to identify the very likely earthquakes. Colluvial wedge is the most common paleoearthquake evidence of reverse faults. Degradation of the fault scarp is indicated in the stratigraphy as a wedge of colluvium. It is derived from the erosion of the top unit on the hanging wall and subsequent in situ deposition above the same 
TABLE 3 | Event indicators and associated stratigraphic units.

\begin{tabular}{|c|c|c|c|c|}
\hline Trench no. & Event & Upper unit & Lower unit & Event indicator \\
\hline 1 & E1-3 & $\mathrm{A} 2$ & A3 & $\begin{array}{l}\text { Colluvial wedge } \\
\text { Upward termination of fault } \\
\text { Vertical offset of unit and colluvial wedge } \\
\text { Greyish-green breccia lens at the bottom of unit A2 }\end{array}$ \\
\hline & E1-2 & A3 & A4 & $\begin{array}{l}\text { Colluvial wedge } \\
\text { Debris at the bottom of unit } A 3 \\
\text { Vertical offset of colluvial wedge }\end{array}$ \\
\hline & E1-1 & A4 & A5 & $\begin{array}{l}\text { Colluvial wedge } \\
\text { Special contact relation of colluvial wedge and unit } \\
\text { Upward termination of fault }\end{array}$ \\
\hline 2 & E2-1 & A1 & $\mathrm{A} 2$ & Deformation of colluvial wedge \\
\hline 3 & E3-1 & $\mathrm{A} 1$ & $\mathrm{~A} 2$ & $\begin{array}{l}\text { Colluvial wedge } \\
\text { Upward termination of fault }\end{array}$ \\
\hline 4 & $\begin{array}{l}\text { E4-2 } \\
\text { E4-1 }\end{array}$ & $\begin{array}{l}\text { Qml } \\
\mathrm{A} 8\end{array}$ & $\begin{array}{l}\text { A7 } \\
\text { A9 }\end{array}$ & $\begin{array}{l}\text { Upward termination of fault } \\
\text { Colluvial wedge }\end{array}$ \\
\hline 5 & E5-1 & A6 & A7 & $\begin{array}{l}\text { Colluvial wedge } \\
\text { Upward termination of fault }\end{array}$ \\
\hline 7 & E7-1 & $\mathrm{B} 1$ & B3 & $\begin{array}{l}\text { Colluvial wedge } \\
\text { Upward termination of fault }\end{array}$ \\
\hline 8 & $\begin{array}{l}\text { E8-3 } \\
\text { E8-2 } \\
\text { E8-1 }\end{array}$ & $\begin{array}{l}\mathrm{B} 1 \\
\mathrm{~B} 2 \\
\mathrm{~B} 2\end{array}$ & $\begin{array}{l}\text { B2 } \\
\text { B2 } \\
\text { B3 }\end{array}$ & $\begin{array}{l}\text { Upward termination of fault } \\
\text { Thin charcoal layer indicating new sag pond } \\
\text { Sag pond sediment } \\
\text { Upward termination of fault } \\
\text { Vertical offset of unit }\end{array}$ \\
\hline 9 & $\begin{array}{l}\text { E9-2 } \\
\text { E9-1 }\end{array}$ & $\begin{array}{l}\mathrm{C} 2 \\
\mathrm{C} 6\end{array}$ & $\begin{array}{l}\mathrm{C} 3 \\
\mathrm{C} 7\end{array}$ & $\begin{array}{l}\text { Sag pond sediment } \\
\text { Colluvial wedge }\end{array}$ \\
\hline 10 & $\begin{array}{l}\mathrm{E} 10-2 \\
\mathrm{E} 10-1\end{array}$ & $\mathrm{C} 3$ & C4 & $\begin{array}{l}\text { Colluvial wedge } \\
\text { Upward termination of fault } \\
\text { Upward termination of fault }\end{array}$ \\
\hline 11 & $\begin{array}{l}E 11-4 \\
E 11-3 \\
E 11-2 \\
E 11-1\end{array}$ & $\begin{array}{l}- \\
\mathrm{C} 2 \\
\mathrm{C} 2 \\
\mathrm{C} 6\end{array}$ & $\begin{array}{l}\mathrm{C} 1 \\
\mathrm{C} 2 \\
\mathrm{C} 3 \\
\mathrm{C} 7\end{array}$ & $\begin{array}{l}\text { Upward termination of fault } \\
\text { Thin charcoal layer indicating new sag pond } \\
\text { Sag pond sediment } \\
\text { Colluvial wedge } \\
\text { Upward termination of fault }\end{array}$ \\
\hline 13 & $\begin{array}{l}E 13-3 \\
E 13-2 \\
E 13-1\end{array}$ & $\begin{array}{l}\text { D5 } \\
\text { D5 } \\
\text { D6 }\end{array}$ & $\begin{array}{l}\text { D5 } \\
\text { D6 } \\
\text { D7 }\end{array}$ & $\begin{array}{l}\text { Thin charcoal layer indicating new sag pond } \\
\text { Upward termination of fault } \\
\text { Sag pond sediment } \\
\text { Material-filled fissure }\end{array}$ \\
\hline 14 & $\begin{array}{l}E 14-3 \\
E 14-2 \\
E 14-1\end{array}$ & $\begin{array}{l}\text { D4 } \\
\text { D6 } \\
\text { D8 }\end{array}$ & $\begin{array}{l}\text { D5 } \\
\text { D7 } \\
\text { D9 }\end{array}$ & $\begin{array}{l}\text { Vertical offset of unit } \\
\text { Upward termination of fault } \\
\text { Vertical offset of unit } \\
\text { Upward termination of fault } \\
\text { Vertical offset of unit } \\
\text { Upward termination of fault }\end{array}$ \\
\hline 17 & $\begin{array}{l}\text { E17-4 } \\
\text { E17-3 } \\
\text { E17-2 } \\
\text { E17-1 }\end{array}$ & $\begin{array}{l}- \\
\text { E4 } \\
\text { E6 } \\
\text { E7 }\end{array}$ & $\begin{array}{l}\text { E1 } \\
\text { E5 } \\
\text { E7 } \\
\text { E8 }\end{array}$ & $\begin{array}{l}\text { Upward termination of fault } \\
\text { Colluvial wedge } \\
\text { Vertical offset of unit } \\
\text { Colluvial wedge } \\
\text { Vertical offset of unit } \\
\text { Sag pond sediment } \\
\text { Vertical offset of unit }\end{array}$ \\
\hline 18 & $\begin{array}{l}\mathrm{E} 18-2 \\
\mathrm{E} 18-1\end{array}$ & $\begin{array}{l}\text { E2 } \\
\text { E4 }\end{array}$ & $\begin{array}{l}\text { E3 } \\
\text { E5 }\end{array}$ & $\begin{array}{l}\text { Sag pond sediment } \\
\text { Material-filled fissure } \\
\text { Upward termination of fault }\end{array}$ \\
\hline 19 & $\begin{array}{l}\text { E19-2 } \\
\text { E19-1 }\end{array}$ & $\begin{array}{l}\text { E3 } \\
\text { E4 }\end{array}$ & $\begin{array}{l}\text { E3 } \\
\text { E5 }\end{array}$ & $\begin{array}{l}\text { Upward termination of fault } \\
\text { Upward termination of fault }\end{array}$ \\
\hline
\end{tabular}

Bold event indicators are the indicators of high quality. 
A

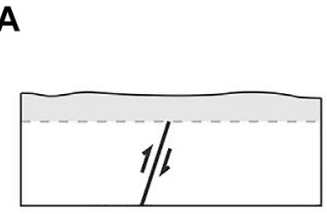

B

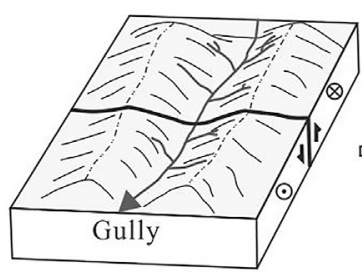

$\vec{b}$

c

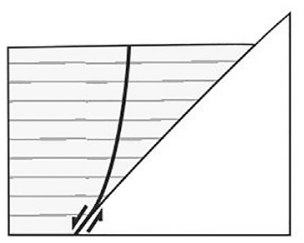

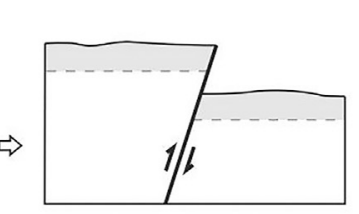

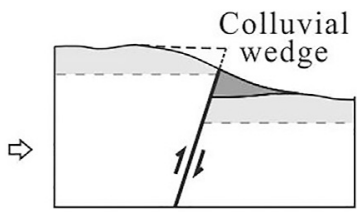

Sag pond
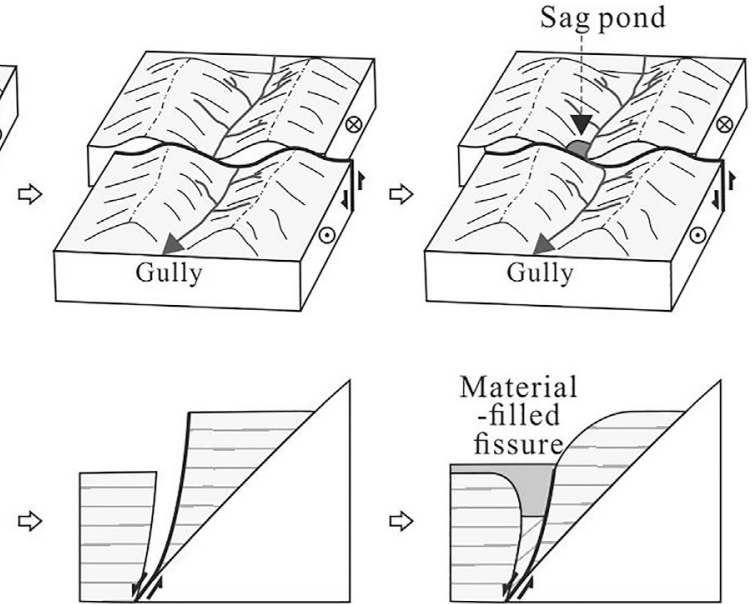

FIGURE 3 | High-quality event indicators and their formation: (A) colluvial wedge, (B) sag pond sediment, and (C) material-filled fissure, modified from (Wallace, 1977; Sieh, 1978; Allen et al., 1991; Bonilla and Lienkaemper, 1991; Nelson, 1992; Fumal et al., 1993; McCalpin, 2005). (A) As the fault moves, a fault scarp forms with the appearance of a free face. During the modification of the free face, until the slope of the fault scarp reaches the repose angle, the hanging wall will be eroded and will provide colluvial debris that accumulates along the degrading scarp as a colluvial wedge on the local footwall. (B) In the valley, a gully flows through the fault. The gully and the mountain on either side will be left-lateral offset by faulting during an earthquake. The gully is locally obstructed by the dislocated mountain of the footwall, and a sag pond forms in which the fine-grained deposits record this earthquake. (C) A normal fault branch develops in the middle of a stratigraphic unit. The unit would be vertically displaced and horizontally separated to open a coseismic fissure as the fault shakes. Assuming that both sides of the fissure are eroded soon after the earthquake, this fissure would be filled with texturally distinct material and then the younger material.

top unit on the footwall (Figure 3A; Wallace, 1977; Nelson, 1992). The wedge-shaped colluvium composed of debris can be often observed near the faults in the footwalls of the trenches along the Gulang fault. Sag pond is a kind of typical offset geomorphology along the strike-slip fault. In the hillside and valley, materials mainly come from the unconcentrated flows and the gullies with small catchment areas. As the fault moves, a sag pond will be formed by the local blockage of flows in which the fine-grained materials deposit to record this earthquake (Figure 3B; Sieh, 1978; Allen et al., 1991; Fumal et al., 1993). These fine-grained sag pond deposits are usually shown as deep-color silt and clay units in the trenches. Material-filled fissures are characterized by vertically displaced and horizontally separated units and out-of-sequence material filling. The fissures are caused by coseismic cracks opening to the ground which are subsequently filled with colluvium and younger sediment (Figure 3C; Bonilla and Lienkaemper, 1991; McCalpin, 2005). They appear to result from nearly vertical or high-angle normal fault branches in the trenches.

Take Trench 17 in Drainage E for example (Figure 2A and Table 3). High-quality event indicator in it includes sag pond sediment and colluvial wedge. The sag pond sediment can identify event E17-1 as a very likely earthquake between units E7 and E8. Events E17-2 and E17-3 can be marked as very likely earthquakes by the colluvial wedges between units E6 and E7 and between unit E4 and unit E5, respectively. But event E17-4 can only be marked as a possible earthquake by the low-quality indicator of the upward termination of fault. Similarly, all events interpreted in the trenches could be classified into very likely earthquakes and possible earthquakes based on the quality of event indicators (Figure 2).

According to the stratigraphic horizons of the event indicators in single-trench stratigraphic sequences, very likely earthquakes and possible earthquakes interpreted in the trenches could be placed between corresponding upper and lower stratigraphic units in the composite stratigraphic sequences of five drainages (Figure 2). Very likely earthquakes identified by the high-quality indicators provide vital evidence for picking out the earthquake horizons. For instance, an earthquake horizon was considered to be located between unit A2 and unit A3 by two very likely earthquakes E1-3 and E3-1 (Figure 2A), from which event EA5 in Drainage A could be identified by this earthquake horizon. Meanwhile, it is supposed that event EA5 occurred during the formation time of this earthquake horizon. It can be constrained by the dating samples within the upper colluvial wedge and in the top of the lower unit A3. Similarly, the paleoearthquakes can be identified by earthquake horizons through the high-quality event indicators. And the timing of their occurrence can be constrained by the ages of the upper and lower units that are determined by the dating samples from multiple trenches (Figure 2). In some cases, there are inconsistent dating results of one stratigraphic unit in different trenches. By avoiding age inversion and considering the dating method, the 


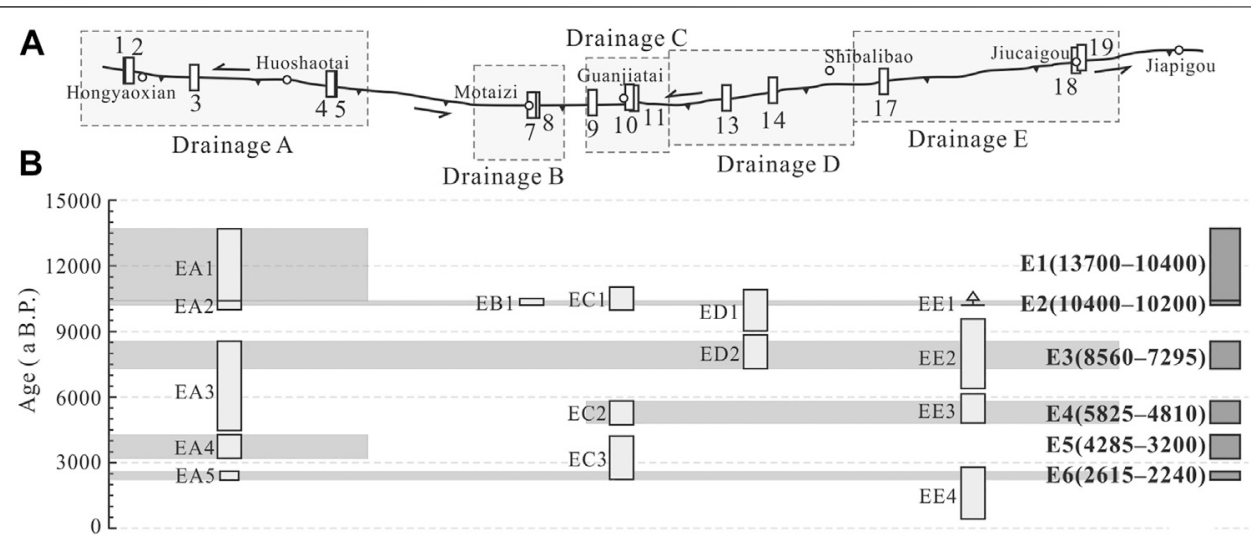

FIGURE 4 | Age limitation of paleoearthquakes of the Gulang fault. (A) Distribution map of the Gulang fault and trench locations. (B) Paleoearthquake sequences of five drainages and the Gulang fault. Events marked by the light gray boxes indicate the paleoearthquakes logged in Drainages A, B, C, D, and E. The gray bars show the fault sections ruptured during the earthquakes. Events marked by the dark boxes are paleoearthquakes of the Gulang fault.

sample type, and relative stable long-term sedimentary rate, the outlier dating samples can be excluded to offer better constraints of the ages of sedimentary units.

\section{RESULTS}

The paleoearthquake sequences were recovered with the composite stratigraphic sequence establishment and event indicator analysis in five drainages. The results show that five events EA1, EA2, EA3, EA4, and EA5 occurred at 13,700-10,400, 10,400-10,000, $8,560-4,470,4,285-3,200$, and 2,615-2,205 a B.P. in Drainage A, respectively (Figure 2A). Only one paleoearthquake, EB1, occurring at 10,500-10,200 a B.P. has been found in Drainage B (Figure 2B). Three paleoearthquakes were logged in Drainage C, including events EC1, EC2, and EC3 occurring at 11,025-9,980, 5,825-4,735, and 4,220-2,240 a B.P., respectively (Figure 2C). Two paleoearthquake, ED1 and ED2, occurred at 10,910-9,025 and $8,840-7,295$ a B.P. in Drainage D (Figure 2D). There were four events EE1, EE2, EE3, and EE4 with an occurrence sequence of $>10,200$, 9,575-6,390, 6,145-4,810, and 2,795-425 a B.P. in Drainage E, respectively (Figure 2E). Combining the paleoearthquake sequences of five drainages, it is supposed that a total of six paleoearthquakes (E1-E6) have occurred on the Gulang fault. The timings of these six events can be constrained to $13,700-10,400, \quad 10,400-10,200, \quad 8,560-7,295, \quad 5,825-4,810$, 4,285-3,200, and 2,615-2,240 a B.P., respectively (Figure 4).

\section{DISCUSSIONS}

\section{Completeness and Reliability of Paleoearthquake Sequence}

The assessment of completeness and reliability of the paleoearthquake sequence identified in the trenches is the precondition for further discussion of the fault behavior. The stratigraphic record of paleoearthquakes is probably incomplete or not reliable enough primarily because 1 ) the site for trench excavation cannot preserve the complete geologic records; 2) some earthquakes have no observable evidence due to the nature of earthquake and subsequent modification; 3) event indicators caused by earthquakes is difficult to be differentiated from the nonearthquake ones; and 4) the resolution and reliability of dating samples are not high enough (Liu-Zeng et al., 2006; Scharer et al., 2007; McCalpin, 2009; Ran et al., 2012b).

Multiple trench constraining method is effective in addressing the incompleteness and unreliability of paleoearthquake sequence. The progressive constraining method usually used before is to arrange the upper and lower age bounds of events interpreted in multiple trenches by time, during which the bounds of some events can be refined step by step, and the age of paleoearthquakes can be estimated (Mao and Zhang, 1995; Zhang et al., 2005). It was also applied to constrain the paleoearthquakes in five drainages of the Gulang fault (Figure 5).

There is some difference between the paleoearthquakes constrained by the progressive constraining method and by the method based on stratigraphic sequences mentioned above (Figure 2, Figure 5). In Drainage E (Figure 2E, Figure 5E), it is possible for event EE'? (event EE4 in Figure 2E) to be missed without the exact evidence of its existence by using the progressive constraining method. It can only be constrained by two lower age bounds interpreted in different trenches without the limitation of an upper bound. Besides, the upper bound of event EE2' (event EE2 in Figure 2E) has been postdated for over 2000 a. This event should be constrained by the dating samples of its upper unit E6 and lower unit E7. The upper bound provided by the dating sample of unit E5 in Trench 19 was wrongly regarded as the upper bound of event EC2' when using the progressive constraining method. Overall, the progressive constraining method strongly depends on the results of the dating samples and event identification of the single trench. And the low-quality event indicators cannot be excluded from event constraints. More trenches are considered, and more problems will arise. The improved multiple trench constraining method we used is capable of preventing these problems by adding composite stratigraphic sequence establishment and event indicator analysis, 


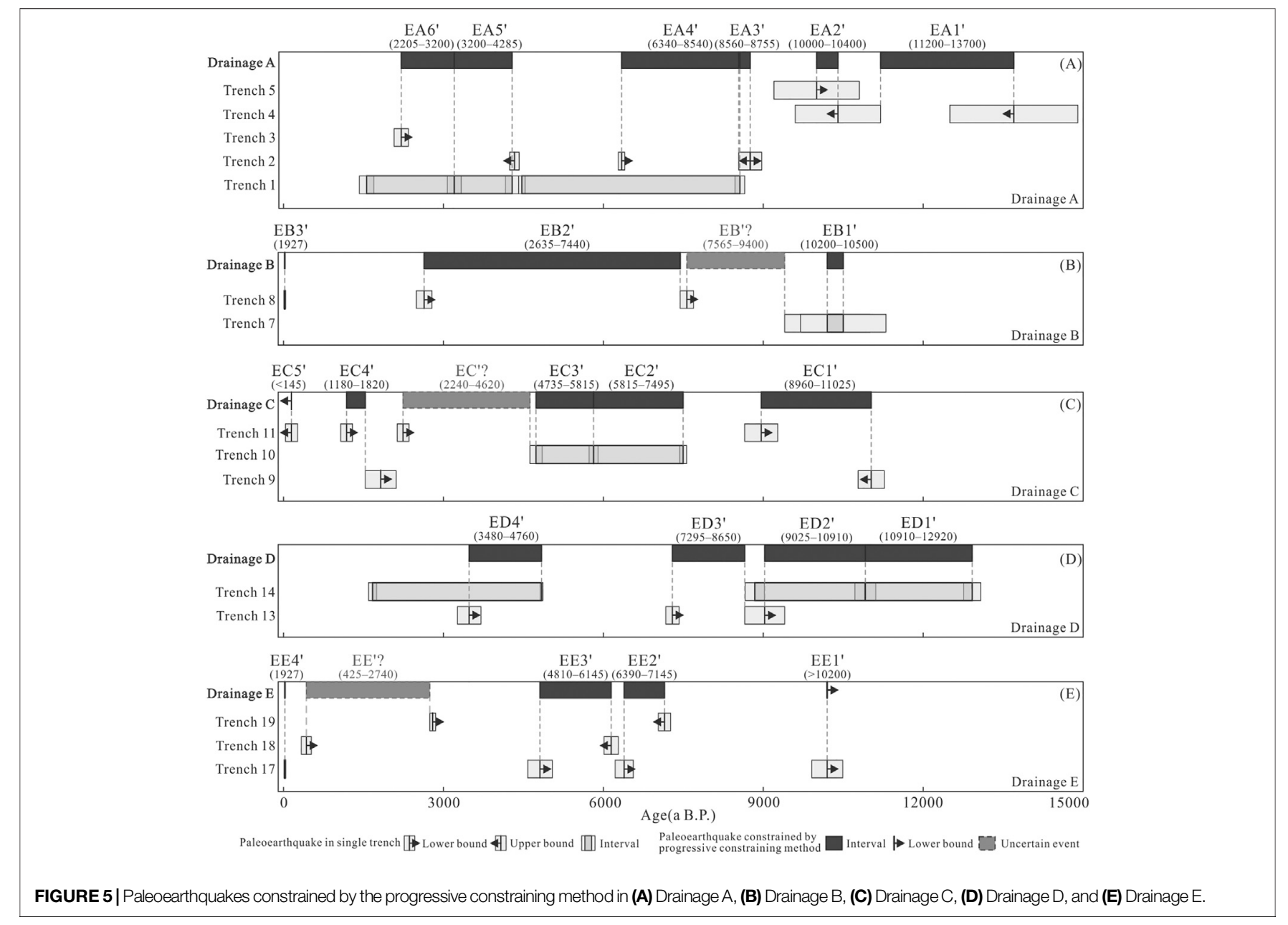

further greatly enhancing the completeness and reliability of the paleoearthquake sequence along the Gulang fault. Besides, the stratigraphic unit correlation gives us a chance to combine more dating samples of multiple trenches and provide a better estimation for the occurrence timings of paleoearthquakes.

\section{Rupture Segmentation of the Gulang Fault}

The Gulang fault is geometrically divided into two segments by the Guanjiatai pull-apart basin (Figure 1C; Dai et al., 1995; Dai et al., 1999; Lanzhou Institute of Seismology, 1995; Zheng et al., 2005). Fault steps over $5 \mathrm{~km}$ are regarded to be persistent barriers of rupture propagation in most circumstances and provide a limit to the rupture length of earthquakes (Wesnousky, 2006; Biasi and Wesnousky, 2016). The scale of the Guanjiatai pull-apart basin between the Tianqiaogou and Huangyangchuan segments is merely several hundred meters. It is too small to control rupture propagations; therefore, it cannot become a termination of the paleoearthquakes along the Gulang fault (Figure 4). Event EC1 and EC3 logged in multiple trenches in Drainage C are cascade ruptures of the Tianqiaogou and Huangyangchuan segments, passing the fault step in Guanjiatai (Figure 2).

The rupture segmentation of active fault is different from the geometric image in some cases; for instance, Gaochuan gets little attention during geometric segmentation but acted as a boundary of the surface rupture zone in Mw7.9 Wenchuan earthquake in 2008 (Xu et al., 2009; Xu et al., 2010; Zhang et al., 2010). Comparing the age ranges of paleoearthquakes recorded in each drainage, the events likely occurring at the same timing can be matched; thus, the rupture extents of these events can be inferred (Figure 4). Discrete fault sections that have demonstrably ruptured during several prehistoric earthquakes are called rupture segments (dePolo et al., 1991; Fumal et al., 1993; McCalpin, 2009). Along the Gulang fault, events E1 and E5 merely ruptured the fault section in Drainage A, while event E4 ruptured the fault sections in Drainages $\mathrm{C}, \mathrm{D}$, and $\mathrm{E}$. The fault might be composed of two rupture segments. One rupture segment is the fault section in Drainage A, termed the western rupture segment, and another consists of fault sections in Drainages C, D, and E, termed the eastern rupture segment herein. Only one entire-fault rupture event, E2, is logged in Drainage B, making it difficult to infer whether the fault section in Drainage B ruptured with the western rupture segment or the eastern rupture segment.

We have collected the left-lateral strike-slip rates of the Gulang fault since the late Pleistocene (Figure 6A; Lanzhou Institute of Seismology, 1995; Zheng et al., 2005; Gao, 2018; Zhang et al., 2019). The slip rate is stable between 2 and $4.5 \mathrm{~mm} / \mathrm{a}$. Its spatial variation along the fault shows that the slip rate is lower between Huoshaotai 

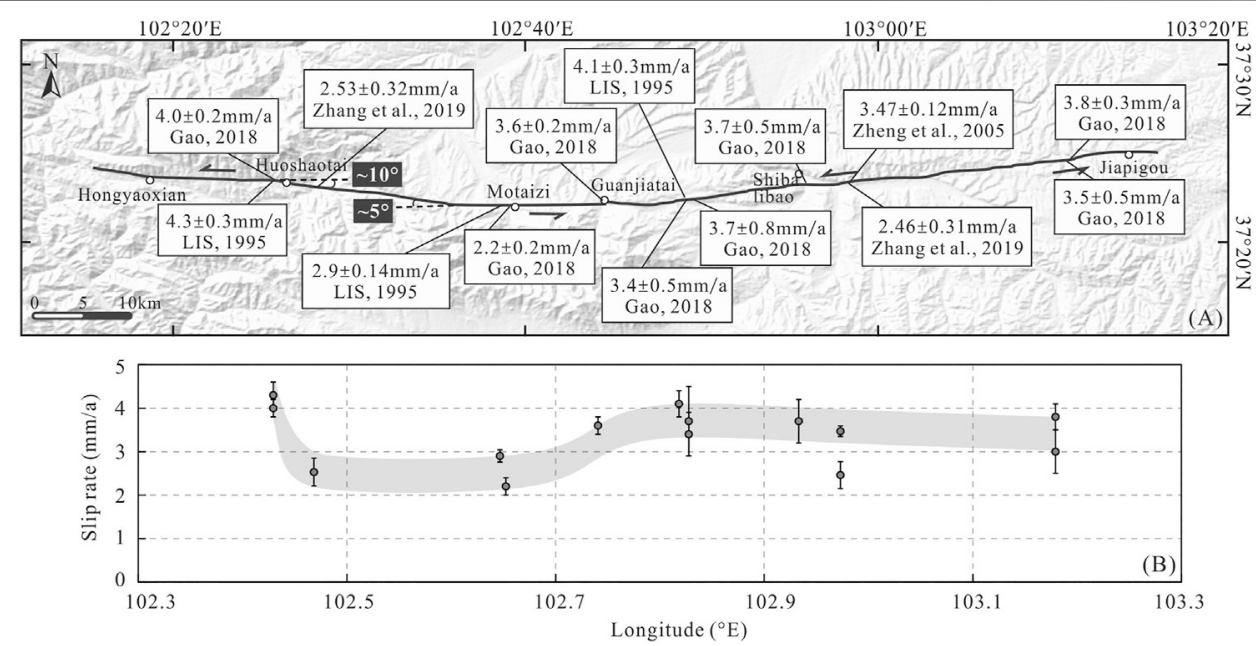

FIGURE 6 | (A) Distribution of left-lateral strike-slip rates along the Gulang fault. The slip rates are from (Lanzhou Institute of Seismology, 1995; Zheng et al., 2005; Gao, 2018; Zhang et al., 2019). Fault traces of the Gulang fault between Huoshaotai and Motaizi show a minor change in fault strike. (B) Spatial variation of slip rates along the Gulang fault.

and Motaizi (Figure 6B). Slip rate change along the fault strike is kinematic evidence of the fault behavioral segmentation (Knuepfer, 1989; Dawers et al., 1993; Dawers and Anders, 1995). The local lower slip rate along the Gulang fault that can be a boundary of fault behavioral segments probably fits the fault section that stopped the rupture propagation during some paleoearthquakes between the western and eastern rupture segments.

Earthquake rupture often terminated at geometric or structural changes of the fault zone (Wesnousky, 1988; McCalpin, 2009). Between Huoshaotai and Motaizi, the fault shows about 5 or $10^{\circ}$ change along strike, yielding a compressive area shown as mountains in geomorphology (Figure 6A). Double restraining bends $>20^{\circ}$ are considered as a termination of earthquake rupture in most cases (Lozos et al., 2011; Elliott et al., 2015; Elliott et al., 2018); nevertheless, minor changes in fault geometry along the strike-slip faults are likely to be conditional barriers to rupture propagation, terminating some earthquakes and allowing others to pass (Duan and Oglesby, 2005; Howarth et al., 2021). The minor change in fault strike between Huoshaotai and Motaizi might be a conditional barrier, stopping some paleoearthquakes between the western and eastern rupture segments and allowing others to complete the entire-fault rupture of the Gulang fault. But it is hard to determine the location of rupture termination via trenching due to the limited precision of horizontal spacing of the trenches between two rupture segments.

\section{Reoccurrence Behavior of the Gulang Fault}

The Gulang fault can be divided into two rupture segments and it shows two scales of paleoearthquake ruptures (Figure 4). Events E2, E3, and E6 represent the entire-fault rupture events. Event E4 is a single-segment rupture event of the eastern rupture segment while events E1 and E5 are single-segment rupture events of the western rupture segment. Four paleoearthquakes were constrained along the eastern rupture segment with the reoccurrence intervals of about 2,370, 2,610, and 2,890 a between events E2, E3, E4, and
E6, respectively. It indicates an average recurrence interval of about 2,620 a. To quantify the paleoearthquake recurrence behavior, the coefficient of variation of the recurrence interval $(\mathrm{Cv})$ was calculated to be 0.10 (Kagan and Jackson, 1991; Berryman et al., 2012). In the western rupture segment, the reoccurrence intervals are about 1750, 2,370, 4,190, and 1,320 a between events E1, E2, E3, $\mathrm{E} 5$, and E6 with Cv to be 0.53 . The earthquake reoccurrence of the eastern rupture segment is of stronger periodicity.

Whether the Gulang fault was ruptured by the 1927 Gulang earthquake or not (Hou, 1998; Zheng et al., 2005; Shi et al., 2019; Zhang et al., 2019) is still controversial. It is an important factor in seismic hazard assessment of the fault. Unfortunately, merely near 100 a has passed since its occurrence hardly forming a complete record in the stratigraphic sequence. There is not enough stratigraphic record in trenches to prove or disprove this historical earthquake along the Gulang fault.

\section{CONCLUSION}

Earthquake-derived surface deformation can lead to the interruption and new beginning of sedimentation near the fault. The high-quality stratigraphic evidence logged in multiple trenches is an important signal to indicate the paleoearthquakes of an active fault. Six paleoearthquakes were constrained along the Gulang fault by using an improved multiple trench constraining method based on the stratigraphic sequence of five drainages. They occurred at 13,700-10,400, 10,400-10,200, $8,560-7,295,5,825-4,810,4,285-3,200$, and 2,615-2,240 a B.P. Compared to the events constrained by the progressive constraining method, it can be proved that the paleoearthquake sequence we obtained is of higher completeness and reliability. The fault could be divided into two rupture segments. The slight variation in fault strike between Huoshaotai and Motaizi probably yields a conditional barrier to rupture propagation. There might be two scales of earthquake rupture: rupture of single rupture segment and rupture of entire 
fault. And two rupture segments showed different reoccurrence behaviors of paleoearthquakes. Besides, the seismogenic fault of the 1927 Gulang earthquake is debatable and it is hard to discuss this event along the Gulang fault by using trench data due to the lack of stratigraphic record.

\section{DATA AVAILABILITY STATEMENT}

The original contributions presented in the study are included in the article, further inquiries can be directed to the corresponding author. The topographic base map of Figure 1 and Figure 6 was generated from 30-m resolution Advanced Spaceborne Thermal Emission and Reflection Radiometer (ASTER) Global Digital Elevation Map (GDEM) data downloaded from the National Aeronautics and Space Administration (NASA; https://asterweb. jpl.nasa.gov/gdem.asp/).

\section{AUTHOR CONTRIBUTIONS}

WZ contributed to the conception of this study. WZ and DZ provided funding for the study. SL, WZ, GC, LD, JY, and HP

\section{REFERENCES}

Allen, C. R., Zhuoli, L., Hong, Q., Xueze, W., Huawei, Z., and Weishi, H. (1991). Field Study of a Highly Active Fault Zone: The Xianshuihe Fault of Southwestern China. Geol. Soc. America Bull. 103, 1178-1199. doi:10.1130/ 0016-7606(1991)103<1178:fsoaha>2.3.co;2

Bacon, S. N., and Pezzopane, S. K. (2007). A 25,000-year Record of Earthquakes on the Owens Valley Fault Near Lone Pine, California: Implications for Recurrence Intervals, Slip Rates, and Segmentation Models. Geol. Soc. America Bull. 119, 823-847. doi:10.1130/b25879.1

Berryman, K. R., Cochran, U. A., Clark, K. J., Biasi, G. P., Langridge, R. M., and Villamor, P. (2012). Major Earthquakes Occur Regularly on an Isolated Plate Boundary Fault. Science 336, 1690-1693. doi:10.1126/science.1218959

Biasi, G. P., and Wesnousky, S. G. (2016). Steps and Gaps in Ground Ruptures: Empirical Bounds on Rupture Propagation. Bull. Seismological Soc. America 106, 1110-1124. doi:10.1785/0120150175

Bonilla, M. G., and Lienkaemper, J. J. (1991). Factors Affecting the Recognition of Faults Exposed in Exploratory Trenches. U.S. Geol. Surv. Bull. 54, 1-32. doi:10.3133/b1947

Burbank, D. W., and Anderson, R. S. (2012). Tectonic Geomorphology. second edition. Chichester: Wiley-Blackwell.

Dai, H. G., Chen, Y. M., Su, X. Z., Jia, Y. H., Liu, H. C., and Hou, K. M. (1995). "Preliminary Study on Paleoearthquake of the Tianqiaogou-Huangyangchuan Fault," in Research on Active Fault (4) (China Earthquake Administration (Beijing: Institute of GeologySeismological Press)), 92-103. in Chinese.

Dai, H. G., Chen, Y. M., Su, X. Z., and Liu, H. C. (1999). Geometry and Kinematics Characteristics of Tianqiaogou-Huangyangchuan Active Fault Zone. Northwest. Seismological J. 21, 259-267. doi:10.1016/j.jsg.2005.10.009

Dawers, N. H., and Anders, M. H. (1995). Displacement-length Scaling and Fault Linkage. J. Struct. Geology. 17, 607-614. doi:10.1016/0191-8141(94)00091-d

Dawers, N. H., Anders, M. H., and Scholz, C. H. (1993). Growth of normal Faults: Displacement-Length Scaling. Geol 21, 1107-1110. doi:10.1130/00917613(1993)021<1107:gonfdl>2.3.co;2

dePolo, C. M., Clark, D. G., Slemmons, D. B., and Ramelli, A. R. (1991). Historical Surface Faulting in the Basin and Range Province, Western North America: Implications for Fault Segmentation. J. Struct. Geology. 13, 123-136. doi:10.1016/0191-8141(91)90061-m improved the multiple trench constraining method. SL collected and analyzed the paleoearthquake data of trenches with the help of WZ and GC. SL wrote the manuscript. All authors contributed to manuscript revision and discussion and approved the submitted version.

\section{FUNDING}

This work was supported by the National Key Research and Development Program of China (no. 2017YFC1500101), the second Tibetan Plateau Scientific Expedition and Research program (STEP) (no. 2019QZKK0901), and the National Science Foundation of China (nos. 41774049 and 41874020).

\section{ACKNOWLEDGMENTS}

We would like to express thanks to Huaguang Dai, Daoyang Yuan, Wei Gao, Feng Shi, and their co-authors for their previous paleoearthquake studies along the Gulang fault that provided fundamental trench data of this study and Xiaohui He, Shiqi Wei, and Ting Liu for their valuable discussions.

Duan, B., and Oglesby, D. D. (2005). Multicycle Dynamics of Nonplanar Strike-Slip Faults. J. Geophys. Res. 110, B03304. doi:10.1029/2004JB003298

Elliott, A. J., Oskin, M. E., Liu-zeng, J., and Shao, Y.-X. (2018). Persistent Rupture Terminations at a Restraining bend from Slip Rates on the Eastern Altyn Tagh Fault. Tectonophysics 733, 57-72. doi:10.1016/j.tecto.2018.01.004

Elliott, A. J., Oskin, M. E., Liu-Zeng, J., and Shao, Y. (2015). Rupture Termination at Restraining Bends: The Last Great Earthquake on the Altyn Tagh Fault. Geophys. Res. Lett. 42, 2164-2170. doi:10.1002/2015gl063107

Ferry, M., Meghraoui, M., Abou Karaki, N., Al-Taj, M., and Khalil, L. (2011). Episodic Behavior of the Jordan Valley Section of the Dead Sea Fault Inferred from a 14-Ka-Long Integrated Catalog of Large Earthquakes. Bull. Seismological Soc. America 101, 39-67. doi:10.1785/0120100097

Fumal, T. E., Schwartz, D. P., Pezzopane, S. K., and Weldon, R. J. (1993). A 100year Average Recurrence Interval for the San Andreas Fault at Wrightwood, California. Science 259, 199-203. doi:10.1126/science.259.5092.199

Gansu Bureau of Geology and Mineral Resources (1989). Regional Geology of Gansu Region. Beijing: Geological Publishing House (In Chinese).

Gao, W. (2018). Late Quaternary Activity of the Tianqiaogou-Huangyangchuan Fault: Implication for the Tectonic Movement Mechanism at the Northeastern Tibet. Beijing: Institute of Geology, China Earthquake Administrator (In Chinese.)

Gaudemer, Y., Tapponnier, P., Meyer, B., Peltzer, G., Shunmin, G., Zhitai, C., et al. (1995). Partitioning of Crustal Slip between Linked, Active Faults in the Eastern Qilian Shan, and Evidence for a Major Seismic gap, the 'Tianzhu gap', on the Western Haiyuan Fault, Gansu (China). Geophys. J. Int. 120, 599-645. doi:10.1111/j.1365-246x.1995.tb01842.x

Goldfinger, C., Grijalva, K., Burgmann, R., Morey, A. E., Johnson, J. E., Nelson, C. H., et al. (2008). Late Holocene Rupture of the Northern San Andreas Fault and Possible Stress Linkage to the Cascadia Subduction Zone. Bull. Seismological Soc. America 98, 861-889. doi:10.1785/0120060411

Guo, P., Han, Z., Mao, Z., Xie, Z., Dong, S., Gao, F., et al. (2019). Paleoearthquakes and Rupture Behavior of the Lenglongling Fault: Implications for Seismic Hazards of the Northeastern Margin of the Tibetan Plateau. J. Geophys. Res. Solid Earth 124, 1520-1543. doi:10.1029/2018jb016586

He, X., Zhang, Y., Shen, X., Zheng, W., Zhang, P., and Zhang, D. (2020). Examination of the Repeatability of Two Ms6.4 Menyuan Earthquakes in Qilian-Haiyuan Fault Zone (NE Tibetan Plateau) Based on Source Parameters. Phys. Earth Planet. Interiors 299, 106408. doi:10.1016/ j.pepi.2019.106408 
Hou, K. M. (1998). Characteristics of Ground Ruptures Caused by 1927 Gulang M8 Earthquake and Their Causative Mechanisms. Seismology Geology. 20, 19-26 (In Chinese). doi:10.1016/s0191-8141(97)00112-0

Hou, K. M., Deng, Q. D., and Liu, B. C. (1999). Research on Tectonic Environment and Seismogenic Mechanism of 1927 Gulang Great Earthquake. Earthquake Res. China 15, 339-348 (In Chinese)

Hou, K. M., Deng, Q. D., and Liu, B. C. (2000). Research on the Tectonic Environment and Seismogenic Mechanism of the 1927 Gulang Great Earthquake with M=8.0. Earthquake Res. China 14, 153-163.

Howarth, J. D., Barth, N. C., Fitzsimons, S. J., Richards-Dinger, K., Clark, K. J., Biasi, G. P., et al. (2021). Spatiotemporal Clustering of Great Earthquakes on a Transform Fault Controlled by Geometry. Nat. Geosci. 14, 314-320. doi:10.1038/s41561-021-00721-4

Kagan, Y. Y., and Jackson, D. D. (1991). Long-Term Earthquake Clustering. Geophys. J. Int. 104(1), 117-133. doi:10.1111/j.1365-246X.1991.tb02498.x

Khajavi, N., Langridge, R. M., Quigley, M. C., Smart, C., Rezanejad, A., and MartínGonzález, F. (2016). Late Holocene Rupture Behavior and Earthquake Chronology on the Hope Fault, New Zealand. Geol. Soc. America Bull. 128, 1736-1761. doi:10.1130/b31199.1

Knuepfer, P. L. K. (1989). Implications of the Characteristics of End-Points of Historical Surface Fault Ruptures for the Nature of Fault Segmentation. U.S. Geol. Surv. Open-File Rep. 89-315, 193-228.

Lanzhou Institute of Seismology (1995). Geological Mapping and Characteristic Earthquake Research Report of Qilian Active Fault. Lanzhou: Lanzhou Institute of Seismology. 1, 500000. in Chinese.

Lasserre, C., Gaudemer, Y., Tapponnier, P., Mériaux, A.-S., Van der Woerd, J., Daoyang, Y., et al. (2002). Fast Late Pleistocene Slip Rate on the Leng Long Ling Segment of the Haiyuan Fault, Qinghai, China. J. Geophys. Res. 107, 4-1. doi:10.1029/2000JB000060

Liu, J., Yuan, Z. D., Xu, Y. R., Shao, Y. X., Xu, J., Lin, Z., et al. (2021). Paleoseismology: Studies of Recurrence Behavior of Large Earthquakes on Active Faults, 28. Beijing: China University of Geosciences. in Chinese. Earth Science Frontiers.

Liu-Zeng, J., Klinger, Y., Sieh, K., Rubin, C., and Seitz, G. (2006). Serial Ruptures of the San Andreas Fault, Carrizo Plain, California, Revealed by ThreeDimensional Excavations. J. Geophys. Res. 111, a-n. doi:10.1029/ 2004JB003601

Liu-Zeng, J., Shao, Y. X., Klinger, Y., Xie, K. J., Yuan, D. Y., and Lei, Z. S. (2015). Variability in Magnitude of Paleoearthquakes Revealed by Trenching and Historical Records, along the Haiyuan Fault, China. J. Geophys. Res. Solid Earth 120, 8304-8333. doi:10.1002/2015jb012163

Lozos, J. C., Oglesby, D. D., Duan, B., and Wesnousky, S. G. (2011). The Effects of Double Fault Bends on Rupture Propagation: A Geometrical Parameter Study. Bull. Seismological Soc. America 101, 385-398. doi:10.1785/0120100029

Mao, F. Y., and Zhang, P. Z. (1995). "Progressive Constraining Method in Paleoseismic Study and Paleoearthquakes along the Major Active Faults in Northern Xinjiang," in Research on Active Fault (4) (China Earthquake Administration (Beijing: Institute of GeologySeismological Press), 153-164 (In Chinese).

McCalpin, J. P. (2005). Late Quaternary Activity of the Pajarito Fault, Rio Grande Rift of Northern New Mexico, USA. Tectonophysics 408, 213-236. doi:10.1016/ j.tecto.2005.05.038

McCalpin, J. P. (2009). Paleoseismology. second edition. Oxford, U. K.: Elsevier.

McCalpin, J. P. (1987). Spatial and Temporal Analysis of 1200 Landslides in a 900 Km2 Area, Middle Rocky Mountains. U.S. Geol. Surv. Open-File Rep. 87-673, $102-114$.

Nelson, A. R. (1992). Holocene Tidal-Marsh Stratigraphy in South-central Oregonevidence for Localized Sudden Submergence in the Cascadia Subduction Zone. Quat. Coasts United States Mar. Lacustrine Syst. SEPM Spec. Publ. 48, 287-301. doi:10.2110/pec.92.48.0287

Ran, Y. K., Wang, H., Li, Y. B., and Chen, L. C. (2012a). Key Techniques and Several Cases Analysis in Paleoseismic Studies in mainland China(1): Trenching Sites, Layouts and Paleoseismic Indicators on Active Strike-Slip Faults. Seismology Geology. 34, 197-210. in Chinese. doi:10.3969/j.issn.02534967.2012.02.001

Ran, Y. K., Wang, H., Li, Y. B., and Chen, L. C. (2012b). Key Techniques and Several Cases Analysis in Paleoseismic Studies in mainland China(2) : Trenching Sites, Layouts and Paleoseismic Indicators on Active Strike-Slip
Faults. Seismology Geology. 34, 385-400. in Chinese. doi:10.3969/j.issn.02534967.2012.03.001

Reimer, P. J., Austin, W. E. N., Bard, E., Bayliss, A., Blackwell, P. G., Bronk Ramsey, C., et al. (2020). The IntCal20 Northern Hemisphere Radiocarbon Age Calibration Curve (0-55 Cal kBP). Radiocarbon 62, 725-757. doi:10.1017/ rdc.2020.41

Ren, Z. K., Zhang, Z. Q., Chen, T., Yan, S. L., Yin, J. H., Zhang, P. Z., et al. (2016). Clustering of Offsets on the Haiyuan Fault and Their Relationship to Paleoearthquakes. Geol. Soc. America Bull. 128, 3-18. doi:10.1130/B31155.1

Scharer, K. M., Weldon, R. J., Fumal, T. E., and Biasi, G. P. (2007). Paleoearthquakes on the Southern San Andreas Fault, Wrightwood, California, 3000 to 1500 B.C.: A New Method for Evaluating Paleoseismic Evidence and Earthquake Horizons. Bull. Seismological Soc. America 97, 1054-1093. doi:10.1785/0120060137

Scharer, K., Weldon, R., Biasi, G., Streig, A., and Fumal, T. (2017). Groundrupturing Earthquakes on the Northern Big Bend of the San Andreas Fault, California, 800 A.D. To Present. J. Geophys. Res. Solid Earth 122, 2193-2218. doi:10.1002/2016jb013606

Schwartz, D. P., and Coppersmith, K. J. (1984). Fault Behavior and Characteristic Earthquakes: Examples from the Wasatch and San Andreas Fault Zones. J. Geophys. Res. 89, 5681-5698. doi:10.1029/jb089ib07p05681

Shen, J., Liu, X. Q., Wang, S. M., and Matsumoto, R. (2005). Palaeoclimatic Changes in the Qinghai Lake Area during the Last 18,000 Years. Quat. Int. 136, 131-140. doi:10.1016/j.quaint.2004.11.014

Shi, F., He, H., Gao, W., Sun, H., Wei, Z., Hao, H., et al. (2019). Holocene Paleoearthquakes on the Tianqiaogou-Huangyangchuan Fault in the Northeastern Boundary Fault System of the Tibetan Plateau. J. Asian Earth Sci. 186, 104049. doi:10.1016/j.jseaes.2019.104049

Sieh, K. E. (1978). Prehistoric Large Earthquakes Produced by Slip on the San Andreas Fault at Pallett Creek, California. J. Geophys. Res. 83, 3907-3939. doi:10.1029/jb083ib08p03907

Sun, Q., and Colin, C. (2014). Paleoclimate and Paleoenvironment of Gonghe Basin, Qinghai-Tibet Plateau, during the Lastdeglacial: Weathering, Erosion and Vegetation Cover Affect Clay Mineral Formation. Acta Geologica Sinica English Edition 88, 647-660. doi:10.1111/1755-6724.12220

Wallace, R. E. (1977). Profiles and Ages of Young Fault Scarps, north-central Nevada. Geol. Soc. America Bull. 88, 1267-1281. doi:10.1130/0016-7606(1977) 88<1267:paaoyf $>2.0$. co;2

Wan, F. L. (1987). Preliminarystudy on Characteristids of Tectonic Activities since Epipleistocene in Huangyangchuan Fault, Gulang Region. Northwest. Seismological J. 9, 97-100. in Chinese.

Weldon, R. J., Fumal, T. E., Powers, T. J., Pezzopane, S. K., Scharer, K. M., and Hamilton, J. C. (2002). Structure and Earthquake Offsets on the San Andreas Fault at the Wrightwood, California, Paleoseismic Site. Bull. Seismological Soc. America 92, 2704-2725. doi:10.1785/0120000612

Wesnousky, S. G. (2006). Predicting the Endpoints of Earthquake Ruptures. Nature 444, 358-360. doi:10.1038/nature05275

Wesnousky, S. G. (1988). Seismological and Structural Evolution of Strike-Slip Faults. Nature 335, 340-343. doi:10.1038/335340a0

Xu, C., Liu, Y., Wen, Y., and Wang, R. (2010). Coseismic Slip Distribution of the $2008 \mathrm{Mw}$ 7.9 Wenchuan Earthquake from Joint Inversion of GPS and InSAR Data. Bull. Seismological Soc. America 100, 2736-2749. doi:10.1785/ 0120090253

Xu, X., Wen, X., Yu, G., Chen, G., Klinger, Y., Hubbard, J., et al. (2009). Coseismic Reverse- and Oblique-Slip Surface Faulting Generated by the $2008 \mathrm{Mw} 7.9$ Wenchuan Earthquake, China. Geology 37, 515-518. doi:10.1130/g25462a.1

Yuan, Z., Liu-Zeng, J., Wang, W., Weldon, R. J., Oskin, M. E., Shao, Y., et al. (2018). A 6000-Year-Long Paleoseismologic Record of Earthquakes along the Xorkoli Section of the Altyn Tagh Fault, China. Earth Planet. Sci. Lett. 497, 193-203. doi:10.1016/j.epsl.2018.06.008

Zhang, P. Z., Wen, X. Z., Shen, Z. K., and Chen, J. H. (2010). Oblique, High-Angle, Listric-Reverse Faulting and Associated Development of Strain: The Wenchuan Earthquake of May 12, 2008, Sichuan, China. Annu. Rev. Earth Planet. Sci. 38, 353-382. doi:10.1146/annurev-earth-040809-152602

Zhang, P., Min, W., Deng, Q., and Mao, F. (2005). Paleoearthquake Rupture Behavior and Recurrence of Great Earthquakes along the Haiyuan Fault, Northwestern China. Sci. China Ser. D-earth Sci. 48, 364-375. doi:10.1360/ 02yd0464 
Zhang, P. Z., Molnar, P., Zhang, W. Q., Deng, Q. D., Wang, Y. P., Burchfiel, B. C., et al. (1988). Bounds on the Average Recurrence Interval of Major Earthquakes along the Haiyuan Fault in north-central China. Seismological Res. Lett. 59, 81-89. doi:10.1785/gssrl.59.3.81

Zhang, Y. P., Zheng, W. J., Zhang, D. L., Zhang, P. Z., Yuan, D. Y., Tian, Q. Y., et al. (2019). Late Pleistocene Left-Lateral Slip Rates of the Gulang Fault and its Tectonic Implications in Eastern Qilian Shan (NE Tibetan Plateau), China. Tectonophysics 756, 97-111. doi:10.1016/j.tecto.2019.02.013

Zheng, W. J., Yuan, D. Y., and He, W. G. (2005). Characteristics of Paleoseismic Activity along the Tianqiaogou-Huangyangchuan Fault on the Eastern Section of the Qilian Mountains. Earthquake Res. China 19, 139-151.

Zheng, W. J., Yuan, D. Y., Zhang, P. Z., Yu, J. X., Lei, Q. Y., Wang, W. T., et al. (2016). Tectonic Geometry and Kinematic Dissipation of the Active Faults in the Northeastern Tibet Plateau and Their Implications for Understanding Northeastward Growth of the Plateau. Quat. Res. 36, 775-788. in Chinese.
Conflict of Interest: The authors declare that the research was conducted in the absence of any commercial or financial relationships that could be construed as a potential conflict of interest.

Publisher's Note: All claims expressed in this article are solely those of the authors and do not necessarily represent those of their affiliated organizations, or those of the publisher, the editors and the reviewers. Any product that may be evaluated in this article, or claim that may be made by its manufacturer, is not guaranteed or endorsed by the publisher.

Copyright (C) 2021 Liang, Zheng, Zhang, Chen, Duan, Yang, Peng and Sun. This is an open-access article distributed under the terms of the Creative Commons Attribution License (CC BY). The use, distribution or reproduction in other forums is permitted, provided the original author(s) and the copyright owner(s) are credited and that the original publication in this journal is cited, in accordance with accepted academic practice. No use, distribution or reproduction is permitted which does not comply with these terms. 